Kavan, N., Özdaş, F. ve Kavan, S. (2021). Türkçe ders kitaplarının soy bağı ilişkileri açısından incelenmesi. Ana Dili Eğitimi Dergisi, 9(4), 1360-1375.

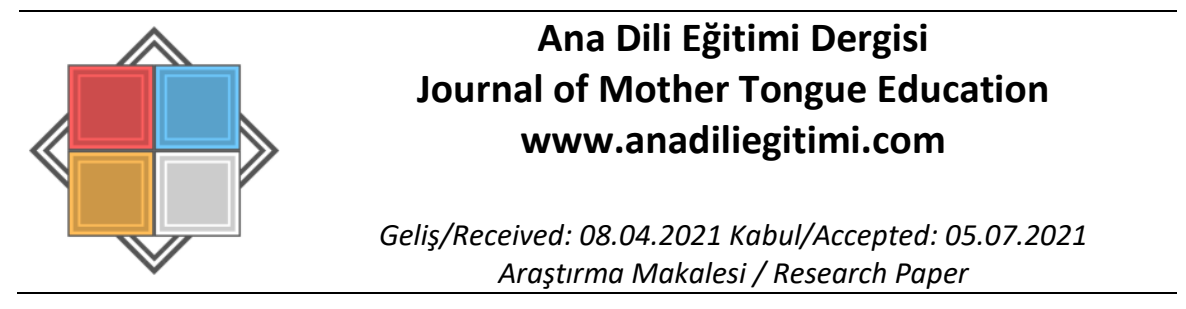

\title{
Türkçe Ders Kitaplarının Soy Bağı ilişkileri Açısından İncelenmesi
}

\author{
Nihat KAVAN* \\ Faysal ÖZDAŞ \\ Seval KAVAN**
}

\begin{abstract}
Öz
$\mathrm{Bu}$ araştırmanın amacı Türkçe ders kitaplarının soy bağı ilişkileri açısından incelenmesidir. Bu amaç doğrultusunda ortaokul 5, 6, 7 ve 8. sınıf Türkçe ders kitaplarında yer alan okuma ve dinleme metinleri soy bağı ilişkileri açısından ele alınmıştır. Araştırmada nitel araştırma yöntemi kullanılarak doküman incelemesi tekniği ile veriler toplanmıştır. Soy bağı ilişkilerinin geçtiği metinler; ele alınan kavramlar, sınıf düzeylerine dağılım, tür dağılımları, görsel unsurlar, kültürel ögeler ve değerler gibi alt amaçlar ile detaylı olarak analiz edilerek bulgular elde edilmiştir. Araştırma sonuçlarına göre Türkçe ders kitaplarında yer alan metinlerin soy bağı kavramları, sınıf düzeylerine dağılım ve değerler eğitimi açısından yeterli ve dengeli olduğu; metin türlerine dağılım, görsel ögeler ve kültürel ögeler açısından yetersiz olduğu tespit edilmiştir.
\end{abstract}

Anahtar Kelimeler: Aile, akraba, soy bağı, ders kitabı, Türkçe dersi.

\section{Abstract}

\section{Analysis of Turkish Textbooks in Terms of Genealogical Relations}

The aim of this research is to examine Turkish textbooks in terms of lineage relations. In accordance with this purpose, reading and listening texts in the 5th, 6th, 7th, and 8th-grade Turkish textbooks are discussed in terms of lineage relations. In the research, data are collected by using the qualitative research method and document analysis technique. The findings are obtained by analyzing in detail the concepts discussed in the texts in which the lineage relationships are mentioned, with sub-purposes such as class-level distribution, genre distribution, visual elements, cultural elements, and values. According to research results, the texts in the Turkish language textbooks are sufficient and balanced in terms of lineage concepts, class-level distribution, and values education, on the other hand, the distribution of the text types is insufficient in terms of visual and cultural elements.

Keywords: Family, relative, lineage, textbook, Turkish lesson.

\section{Giriş}

Bir toplumu, toplum yapan ve insanları bir araya getirerek birbirine bağlayan, onları diğer milletlerden ayıran değerler, millî kültürü oluşturmaktadır. Millî kültürün temel yapı taşlarından birisi de soy bağı ilişkilerinin bilinmesi ve soy bağlarının korunmasıdır. Nesilden nesile kültürün aktarılmasında rol oynayan soy bağı ilişkilerine örgün ve yaygın eğitim sürecinde ders kitaplarında yer verilmesi kültür aktarımında önem arz etmektedir.

Küreselleşmenin gelişmesi ile beraber dünya algısı küçülmüş ve ülkeler arasındaki ilişkiler daha kapsamlı ve gelişmiş hâle gelmiştir. Farklı kültürel değerlere sahip ülkelerin millî ve manevi

\footnotetext{
* Bilim Uzmanı, nihatkavan@gmail.com, ORCID: 0000-0003-4872-1002

** Doç. Dr., Mardin Artuklu Üniversitesi, Edebiyat Fakültesi, Eğitim Bilimleri Bölümü, Mardin, faysalozdas@artuklu.edu.tr, ORCID: 0000-0002-2261-9504

*** Öğretmen, Millî Eğitim Bakanlığı, Mardin, seval1420@gmail.com, ORCID: 0000-0002-0852-0516
} 
değerlerinin birikimi ulusal sınırları aşmıştır (Karadağ, Kolaç ve Ulaş, 2012). Bilişim teknolojilerindeki bu hızlı değişim ve gelişmeler toplumların; sağlık, kültür, siyasî, ekonomik ve eğitim alanlarında önemli değişikliklere neden olmaktadır (Adıgüzel, 2010). Küreselleşen dünyada bilgiye ulaşma kolaylık kazanmış ve insanların bundan istifade ederek etkilenmesi kolaylaşmıştır (Demir ve Akkaya, 2020). Hızlı artan bu küreselleşme, toplumların millî unsurlarını da etkilemekte ve toplum yapısında çeşitli değişimlere sebep olabilmektedir.

Akrabalık birey ile toplum arasındaki ilişkileri; ebeveynler ile çocuklar, kardeşler ve evli çiftler arasındaki ilişkilere göre düzenleyen bir sistemdir (Marshall, 1999). Soy bağı ise aynı toplumda yaşayan bireylerin birbirlerine karşı hak ve sorumluluklar benimsediği toplumsal kavramdır (Haviland vd., 2008). Türk millî eğitiminin genel amaçlarından biri olan "Türk milleti millî ahlaki, insani, manevi ve kültürel değerlerini benimseyen, koruyan ve geliştiren ailesini, vatanını, milletini seven ve daima yüceltmeye çalışandır (MEB, 1973)" ibaresi Türk milletinin aile ve akraba kurumuna verdiği önemi vurgulamaktadır. Soy bağı kavramalarını bilen ve benimseyen fertler bu değerlere bağlı kalabilir.

Türkçe dersinin temel materyali olan ders kitaplarında yer alan metinlerde kültürel değerlerin önemli ögelerinden olan soy bağı kavramlarına yeterince yer verilmeli ve bu kavramlara uygun metinler seçilmelidir (Şahin, 2015). Eğitim öğretim sürecinin vazgeçilmez bir parçası olan ders kitaplarının soy bağı terimlerini öğretme konusunda önemli bir rolü olmalıdır (Çelikpazu ve Aktaş, 2011). Çocuklar doğdukları zaman, içinde yaşadıkları toplumun toplumsal kurallarını ve kültürel değerlerini bilmemektedirler. Çocukların toplumsal kuralları ve ilkeleri öğrenmesi ve benimsemesi sosyalleşme sonucu gerçekleşmektedir (İnanç, 2004). Çocukların sosyalleşebilmeleri öncelikli olarak soy bağı ilişkilerini edinmeleri ve bu ilişkilerin onlara aktarılması ile sağlanır. Soy bağı kavramlarını öğrenme, öğretme sürecinde ders kitaplarının önemi büyüktür. Ders kitapları tek elden Millî Eğitim Bakanlığı tarafından denetlenip tüm öğrencilere sunulduğu için ülke genelinde her öğrenciye ulaşmaktadır. Bu sebeple ders kitaplarında yer alan metinler, metinlerin içerikleri, metinlerin başlıkları gibi unsurlar soy bağı kavramları ile ilişkili olacak şekilde seçilmelidir. Ders kitaplarında yer alan metinlerle çocukların sözcük dağarcığının soy bağı terimleri ile zenginleştirilmesi hedeflenmelidir (Türkben, 2019).

Türkçe öğretiminde soy bağı aktarımının yapılması bireylerin topluma uyumunun sağlanması için önem arz etmektedir. Türkçe derslerinde öğretmenlerin kullandığı metinler, soy bağı kavramını aktarmanın en önemli materyalleridir. Bu sayede öğrenciler kendi soy bağı kimliklerini tanıma, ilişkilendirme ve bu kavramaları karşılaştırıp zihinlerinde şemalar oluşturma fırsatı bulmaktadır.

Yaşadığımız yüzyılda her alanda kendini gösteren hızlı değişim ve gelişim, daha önce hiç görülmemiş bir hızda ilerleyen dönüşümü de beraberinde getirmektedir (Belet Boyacı ve Güner Özer, 2019). Doğum oranlarının düşmeye başlamasıyla beraber gittikçe yatay akrabalık kategorileri yok olmaya başlamaktadır. Kardeşler, amcalar, teyzeler, yeğenler, kuzenler ve benzeri yatay akrabalık kategorilerinin azalmaya hatta kimi bireyler için yok olmaya başlaması ile toplumsal yaşamda neler değişti ya da değişecek, insan ilişkilerinin soy bağından beslenemeyen neslin kendi damarlarından beslenemeyen ağaç gibi kültürünü bilmeden, özünü bilmeden oluşumunu nasıl tamamlayabilecek sorusu sorulmaya başlandı (Özbay, 2014).

Soy bağı kimliğinin korunmasının giderek zorlaştığı dünyada insanlar ve aynı soy bağındaki insanlar arasındaki ilişkiler gittikçe zayıflamaktadır. Bu durum eğitimde kültür ve soy bağı kavramları üzerinde durulması gerektiğinin altını çizmektedir (Emiroğlu, 2012). Modern dünyada millî ve kültürel kimliğini, soy bağı ilişkilerini koruyarak kendi kültürünü muhafaza edebilen nesiller yetiştirmek git gide zorlaşmaktadır. Gelişip değişerek ilerleyen teknoloji toplumun çekirdek yapısından başlayarak sosyolojik ve kültürel değişikliklerle soy bağı ilişkilerinin korunmasını ve genç kuşakların bu ilişkilere sahip çıkmasını günbegün zorlaştırmaktadır (Tuztaş, 2004).

Yapılan bu araştırmanın amacı Türkçe ders kitaplarındaki metinlerin, aile ve akraba gibi soy bağları ilişkilerini ele alışları açısından inceleyip değerlendirmektir. Bu bağlamda Millî Eğitim Bakanlığının 2020-2021 eğitim-öğretim yılında ortaokul kademesinde okutmakta olduğu 5, 6, 7 ve 8 . sınıf Türkçe ders kitapları soy bağı ilişkileri açısından incelemiştir. Araştırma ile beraber Türkçe ders kitaplarının akrabalık ilişkilerini çocuklara aktarma işlevlerinin tespiti amaçlanmıştır. Okulun temel görevleri arasında öğrencilerin bir bütün olarak geliştirmesi yer almaktadır. Burada bireyin ruh, 
beden, zihin ve duygularına hitap ederek, bireyin her bakımdan dengeli geliştirilmesi önemlidir. Böylece bireyin kendini ve doğal çevresini tanımasına ve bilinçli ilişkiler kurmasına imkân sağlanmış olur (Akpınar, 2013). Soy bağı ilişkilerinin okulda öğrencilere kazandırılması bireysel ve toplumsal açıdan kazanımlara sebep olabilir. Soy bağının bilinmesi ve öğrenilmesiyle bireyin kendini ve toplumunu tanımasına yardımcı olması, toplumsal huzur, birlik ve beraberliğin sağlaması açısından önemlidir.

Soy bağı, insanları bir araya getiren ve birbirine bağlayan temel nedenlerin başında gelmektedir. Soy bağı ilişkilerinin okulda öğrencilere kazandırılmasının bireysel ve toplumsal açıdan kazanımlara yol açacağı düşünülmektedir. Soy bağının bilinmesi bireyin kendini ve toplumunu tanımasına yardımcı olması, toplumsal huzur, birlik ve beraberliğin sağlaması açısından önemlidir. Araştırma Türkçe ders kitaplarındaki metinlerde yer alan soy bağı ilişkilerinin öğrencilere aktarılması ve benimsetilmesi adına kavramların; eğitime etkisinin belirlenmesi, ders kitaplarında aile ve akraba ilişkilerine verilen değerin tespiti ile varsa bu alandaki eksikliklerin ortaya konulması açısından önem taşımaktadır.

Araştırmanın amacından hareketle aşağıdaki alt amaçlara cevap aranmıştır:

1. Soy bağı ilişkilerini içeren metinlerde hangi soy bağı kavramlarına yer verilmiştir?

2. Soy bağı ilişkilerini içeren metinler sınıf düzeylerine dengeli dağıımış mıdır?

3. Soy bağı ilişkileri metin türlerine dengeli dağılmış mıdır?

4. Soy bağı ilişkilerini ele alan metinler görsellerle desteklenmiş midir?

5. Soy bağı konusu ile öğrencilere hangi değerler kazandırımak istenmiştir?

6 . Soy bağı konusu ile ilgili metinlerde hangi kültürel ögelere yer verilmiştir?

\section{Araştırmanın Modeli}

\section{Yöntem}

Millî Eğitim Bakanlığının Türkçe ders kitaplarında işlenen soy bağı ilişkileri ile bunların ne amaçla ve nasıl kullanıldığının incelendiği bu araştırmada nitel araştırma yöntemi kullanılmıştır. Araştırma kapsamında veri toplamak için veri toplama tekniklerinden doküman incelemesi tekniği kullanılmıştır. Doküman inceleme, araştırmanın amacına uygun olarak olay, olgu ve bilgilerin yer aldığı görsel, işitsel ve elektronik kaynak ve materyallerin incelenip değerlendirildiği bir tekniktir (Yıldırım ve Şimşek, 2018). Bu teknikte araştırma kapsamına konu olan olay, olgu, birey veya nesne içinde bulunduğu koşullar içinde olduğu gibi tanımlanmaya çalışılır. Onları, herhangi bir şekilde değiştirme, etkileme çabası gösterilmez. Önemli olan bilinmek istenen şeyin gözlenip belirlenebilmesidir" (Karasar, 2006).

\section{Çalışma Materyali}

Araştırma kapsamında Millî Eğitim Bakanlığı tarafından 2020-2021 eğitim ve öğretim yılında ortaokullarda okutulan Türkçe ders kitapları çalışma materyalleri olarak kullanılmıştır. Veri toplamada yararlanılan ders kitapları Tablo 1'de sunulmuştur.

Tablo 1.

incelenen Çalışma Materyalleri

\begin{tabular}{|c|c|c|c|}
\hline Kitabın Adı & Yayınevi & Yazar & Basım Yılı \\
\hline 5. Sınıf Türkçe Ders Kitabı & Anıttepe Yayıncılık & $\begin{array}{l}\text { Şule Çapraz Baran } \\
\text { Elif Diren }\end{array}$ & 2019 \\
\hline 6. Sınıf Türkçe Ders Kitabı & Ekoyay Yayıncılık & Tuncay Demirel & 2019 \\
\hline 7. Sınıf Türkçe Ders Kitabı & Özgün Matbaacılık & $\begin{array}{l}\text { Hilal Erkal } \\
\text { Mehmet Erkal } \\
\text { Hilal Eselioğlu }\end{array}$ & 2019 \\
\hline 8. Sınıf Türkçe Ders Kitabı & Tuna Matbaacılık & $\begin{array}{l}\text { Sıdıka Set } \\
\text { Ayşe Yücel }\end{array}$ & 2019 \\
\hline
\end{tabular}


Bu araştırma:

1. 2020-2021 eğitim-öğretim yılında okutulun ortaokul 5, 6, 7 ve 8. sınıf Türkçe ders kitaplarıyla,

2. Türkçe ders kitaplarında yer alan okuma ve dinleme/izleme metinleriyle,

3. Soy bağı ilişkilerinin geçtiği metinlerle sınırlandırılmıştır.

\section{Verilerin Toplanması}

Araştırma verilerinin toplanmasında nitel veri toplama tekniklerinden olan doküman incelemesi kullanılmıştır. Yapılan araştırmada Millî Eğitim Bakanlığının ortaokullarda okuttuğu 5, 6, 7 ve 8. sınıf Türkçe ders kitaplarında yer alan; her bir ders kitabında 24 okuma metni olmak üzere 96, her bir ders kitabında 8 dinleme/izleme metni olmak üzere 32 ve her bir ders kitabında 8 serbest okuma metni olmak üzere 32, toplamda 160 metin soy bağı ilişkileri açısından taranarak verilerin toplanmasına kaynak oluşturmuştur. Bu bağlamda ders kitaplarında yer alan metinlerin soy bağı ilişkilerini ele alıp almadıkları, hangi soy bağı kavramlarını ele aldıkları, sınıf düzeylerine dengeli dağıtılıp dağıtılmadıkları, metin türlerine dengeli dağıtııp dağıtılmadıkları, görsellere yer verilip verilmediği, kültürel ögelere ve değerlere yer verilip verilmediği gibi sorulara cevap aranarak incelenmiş olup metinlerin durum ve içeriklerine göre değerlendirilmiştir.

\section{Verilerin Analizi}

Doküman inceleme yöntemiyle toplanan veriler içerik analizi ile analiz edilmiştir. "Nitel araştırmalarda dokümanların incelenmesinde içerik analizi kullanılmaktadır" (Merriam, 1998, s. 123). İçerik analizinde birbirine benzeyen bazı kavramlar ve temalar bir araya getirilerek okuyucunun anlayacağı biçimde düzenlenip yorumlanmaktadır. İçerik analizinin temel amacı, toplanan verileri açıklayabilecek kavramlara ulaşma, kavramları mantıklı bir şekilde düzenleme ve verileri açıklayacak temalara ulaşmadır (Yıldırım ve Şimşek, 2018).

Belirlenen ölçütlere yönelik olarak yapılan kaynak taramasında verilerin analizinde araştırmacılar tarafından oluşturulan aşağıdaki ölçütler esas alınmıştır:

Inceleme kapsamında ele alınan ders kitapları doküman incelemesi yapılarak her sınıf düzeyinde ayrı ayrı olmak üzere ayrıntılı bir şekilde okunarak soy bağı ilişkisinin yer aldığı veriler, bulgular başlığı altında yer alan alt amaçlara ilişkin cevaplarla sunulmuştur. Her sınıf seviyesindeki metinde tespit edilen soy bağı ilişkilerinden doğrudan alıntılar yapılarak yorumlanmıştır. Söz konusu ilişkilerde saygı amaçlı söylenen baba, dayı, dede, nene gibi söylemler araştırma kapsamına dâhil edilmeyerek sadece soy bağı amaçlı söylemler ele alınmıştır.

İncelenen ders kitaplarında soy bağı ilişkilerini içeren 42 metin tespit edilmiştir. Soy bağı ilişkilerini içeren metinler verilerin analizini ve okunmayı kolaylaştırmak için metin kelimesinin baş harfine sayı verilerek "M1, M2, M3 vb." olacak şekilde kısaltmalarla kodlanmıştır. Metinlere ilişkin kodlar Tablo 2' de sunulmuştur.

Tablo 2.

Soy Bağı ilişskilerini Içeren Metinler

\section{Sınıf Seviyesi}

\section{Sinıf}

M1-Bir Temmuz

Gecesi

M2-Deprem

M3-Boğaç Han

Metin Adı M4-Çocuk Bahçesindeki Bekçi

M5-Çiftçi ile

Çocukları

M6-Çitlembik

6. Sinif

M11-Meşeler M12-Elveda

Ağustos Böceği

M13-Kediyle Kaplan

M14-Kuşların

Çektiği Kağnı

M15-Oyun

M16-Azim

M17-Gazlı Göl
7. Sinıf

M23-Ninemin Kitabı M35-Kaşağı

M24-Baba, Bana Bir M36-Kınalı Ali'nin

Şiir Bul

M25-Sol Ayağım

M26-Bayrağımızın

Altında

M27-Güler Yüz

M28-Büyük Mimar

Koca Sinan
Mektubu

M37-Atatürk'ü

Gördüm

M38-Simit ve

Peynir'le Bilim

Insanı Öyküleri

M39-Portakal 


\section{Sınıf Seviyesi}

5. Sinıf

6. Sinıf

7. Sinıf

8. Sinıf

\begin{tabular}{cllll}
\hline & M7-Dedemin & M18-Forsa & M29-Küçük Yunus & M39-Portakal \\
& Öyküsü & M19-Nineme Ninni & M30-Son Leylek & M40-Karanlığın \\
& M8-Büyüklere Saygı & M20-içimdeki & M31-Karagöz ile & Rengi Beyaz \\
M9-Yaşama Sevinci & Müzik & Hacivat & M41-Kız Kulesi \\
\multirow{4}{*}{ Metin Adı } & M10-Bir Bardak & M21-Yaz Sinemaları & M32-Karamsar ve & M42-Karagöz \\
& Sütün Hatırı & M22-Seyfi Dede & İyimser Bakış Açısı & \\
& & & M33-Bilmemekten & \\
& & & Rahatsız Olmayın & \\
& & & M34-ibni Sina & \\
\hline
\end{tabular}

Toplam

42

\section{Verilerin Geçerlik ve Güvenirliği}

Türkçe ders kitaplarının incelenmesinde araştırmacılar tarafından oluşturulan alt amaçlar içerik analizi ile ilk olarak tüm metinler daha sonra soy bağı ilişkilerini içerdiği tespit edilen metinler olmak üzere tek tek incelenerek analiz edilmiştir. Sonuçların inandırıcılığı, bilimsel bir araştırmanın en önemli ölçütlerinden biri olarak kabul edilmektedir. Geçerlik ve güvenirlik bu açıdan araştırmalarda en yaygın kullanılan ölçütlerdir (Yıldırım ve Şimşek, 2018). Nitel araştırmalarda geçerlik ve güvenirliği sağlamanın en önemli aşamaları araştırmacıların veri toplama, veri analizi ve verilerin yorumlanması süreçlerinde tutarlı davranarak araştırmanın tüm aşamalarını açık ve net bir şekilde ifade etmeleridir (Özdaş ve Çakmak, 2018).

Araştırmanın geçerlik ve güvenirliğini sağlamak için aşağıda belirtilen önlemler alınmıştır:

- Bulguların doğruluğunu sağlamak için farklı araştırmacılardan yararlanılmıştır.

- Verilerin tanımlanmasında ve yorumlanmasında araştırmacılar nesnel olmaya çalışmıştır.

- Verilerin toplanmasında araştırmacılar tarafından ortaklaşa kabul edilen veriler araştırmaya dâhil edilerek ihtilafa düşülen veriler araştırmanın güvenirliği açısından araştırmaya dâhil edilmemiştir.

- Verilerin toplanmasında ve analizinde araştırmacılar arasında uzlaşma sağlanmıştır.

- Verilerin yorumlanmasında ve sunulmasında ders kitaplarından doğrudan alıntılar yapılmıştır.

\section{Araştırma ve Yayın Etiği}

Bu araştırmada "Yükseköğretim Kurumları Bilimsel Araştırma ve Yayın Etiği Yönergesi" kapsamında uyulması belirtilen tüm kurallara uyulmuştur. Yönergenin ikinci bölümü olan "Bilimsel Araştırma ve Yayın Etiğine Aykırı Eylemler" başlığı altında belirtilen eylemlerden hiçbiri gerçekleştirilmemiştir.

\section{Bulgular}

Araştırmanın bu bölümünde araştırmaya konu olan Türkçe ders kitaplarında yer alan soy bağı ilişkileri ile ilgili cevap aranan alt amaçlara ilişkin veriler yer almaktadır. Ulaşılan veriler araştırmanın alt amaçları dâhilinde sunulmuştur.

\section{Birinci Alt Amaca İlişkin Bulgular ve Yorum}

Araştırmanın birinci alt amacını oluşturan "Soy bağı ilişkilerini içeren metinlerde hangi soy bağı kavramlarına yer verilmiştir?" sorusuna ilişkin bulgular ve yorumlar Tablo 3'te sunulmuştur. 
Tablo 3.

Soy Bağı Iliş̧kili Kavramların Dağılımı

\begin{tabular}{|c|c|c|c|c|c|c|}
\hline \multirow{2}{*}{ Kavram } & \multicolumn{4}{|c|}{$\underline{\text { Sinıf Seviyesi }}$} & \multirow{2}{*}{$f$} & \multirow{2}{*}{$\%$} \\
\hline & 5. Sinıf & 6. Sinıf & 7. Sinif & 8. Sinıf & & \\
\hline Baba & 27 & 29 & 21 & 55 & 132 & 24,08 \\
\hline Anne, Ana & 16 & 24 & 30 & 33 & 103 & 18,79 \\
\hline Erkek Evlat, Oğul & 32 & 11 & 18 & 17 & 78 & 14,23 \\
\hline Nine, Anneanne & 4 & 14 & 25 & - & 43 & 7,84 \\
\hline Kız Evlat & - & 6 & 18 & 13 & 37 & 6,75 \\
\hline Kardeş & 11 & 2 & 5 & 14 & 32 & 5,83 \\
\hline Dayı & 1 & 13 & 12 & - & 26 & 4,74 \\
\hline Ağabey, Abi & 12 & 1 & - & 12 & 25 & 4,56 \\
\hline Dede & 15 & - & 6 & 4 & 25 & 4,56 \\
\hline Aile & 4 & 4 & 10 & - & 18 & 3,28 \\
\hline Torun & - & - & 6 & 1 & 7 & 1,27 \\
\hline Yeğen & - & 6 & - & - & 6 & 1,09 \\
\hline Abla, Bacı & - & 2 & - & 2 & 4 & 0,72 \\
\hline Akraba, Soy & 3 & 1 & - & - & 4 & 0,72 \\
\hline Amca, Emmi & 2 & - & - & 2 & 4 & 0,72 \\
\hline Eş, Karı, Koca & - & 2 & - & - & 2 & 0,36 \\
\hline Teyze & 1 & - & - & - & 1 & 0,18 \\
\hline Yenge & - & - & - & 1 & 1 & 0,18 \\
\hline Toplam & 128 & 115 & 151 & 154 & 548 & 100 \\
\hline
\end{tabular}

Türkçe ders kitapları soy bağı ilişkileri açısından incelendiğinde 18 farklı kavramın toplam 548 defa metinlerde geçtiği tespit edilmiştir. Bu kavramlar ile beraber eş anlamlı olan ilişkili kavramlar da farklı bir kavram olarak değil ana kavramla birlikte ele alınmıştır. Bu kavramlar bir bütün olarak incelendiğinde en çok baba $(f=132)$, en az ise yenge $(f=1)$ ve teyze $(f=1)$ kavramlarının ders kitaplarında yer aldığı görülmektedir. Kavramlar sınıf seviyeleri açısından ele alındığında ise en fazla kavram sayısının Tuna Yayıncılık tarafından yayımlanan 8. sınıf $(f=154)$ ders kitabında yer aldığı, en az kavramın ise Ekoyay Yayıncılık tarafından yayımlanan 6. sınıf $(f=115)$ ders kitabında yer aldığı görülmektedir.

Baba; ba çocuk sesinden türeyip kızan, karışan, sinirlendiren, özlenen, değeri yokluğunda anlaşılan bu kelime dilimize herhangi bir dilden girmemiş, genel olarak birçok dilde farklı varyantlarla kullanılmaktadır (Ertuğrul ve Ertuğrul, 2016). Ders kitaplarında yer alan soy bağı ilişkili kavramların frekans değerleri incelendiğinde kavramlar arası dengeli bir dağılım olamadığı, bazı kavramların çok fazla tekrarlanırken bazı kavramların yok denecek kadar az tekrarlandığı bulgusu elde edilmiştir. Soy bağı ilişkilerini içeren metinlerde geçen bazı soy bağı kavramları ile ilgili doğrudan alıntılar aşağıda sunulmuştur:

"Daha sonra babam hepimizi alıp şehrin öbür yanındaki büyük bir binaya götürdü." (Çapraz Baran ve Diren, 2019, s. 86).

"Anneler, savaş filmlerinde ölen askerlere acırlardı en çok." (Demirel, 2019, s. 223).

"Dedeciğim, acaba biz de böyle büyük yapılar yapamaz mıyız?" (Erkal ve Erkal, 2019, s. 109).

"Üç sofra kurulurdu; biri dedem ve emmilerime, biri büyük gelinlerle ebeme, biri de küçük gelinlerle onların çocuklarına." (Eselioğlu, Set ve Yücel, 2019, s. 122). 


\section{íkinci Alt Amaca İlişkin Bulgular ve Yorum}

Araştırmanın ikinci alt amacını oluşturan "Soy bağı ilişkilerini içeren metinler sınıf düzeylerine dengeli dağılmış mıdır?" sorusuna ilişkin bulgular ve yorumlar Tablo 4'te sunulmuştur. Soy bağı ilişkilerini içeren metinlerin sınıf düzeylerine dağılımında ölçüt olarak oransal dağılım esas alınmıştır.

Tablo 4.

Soy Bağı Ilişskili Metinlerin Sınıf Seviyelerine Dağılımı

\begin{tabular}{llc}
\hline Sinıf Seviyesi & \multicolumn{1}{c}{ Metin } & $f$ \\
\hline 5. Sinıf & $M 1, M 2, M 3, M 4, M 5, M 6, M 7, M 8, M 9, M 10$ & 10 \\
6. Sinif & $M 11, M 12, M 13, M 14, M 15, M 16, M 17, M 18, M 19, M 20, M 21, M 22$ & 12 \\
7. Sinıf & $M 23, M 24, M 25, M 26, M 27, M 28, M 29, M 30, M 31, M 32, M 33, M 34$ & 12 \\
8. Sinif & M35, M36, M37, M38, M39, M40, M41, M42 & 8 \\
\hline Toplam & & 42 \\
\hline
\end{tabular}

Türkçe ders kitaplarının incelenmesi neticesinde en fazla kullanılan soy bağı ilişkili metinlerin Ekoyay Yayıncılık tarafından yayımlanan 6. sınıf $(f=12)$ ve Özgün Matbaacılık tarafından yayımlanan 7. $\operatorname{sınıf}(f=12)$ ders kitaplarında yer aldığı, en az metinlerin ise Tuna Matbaacılık tarafından yayımlanan 8. $\operatorname{sınıf~}(f=8)$ ders kitaplarında yer aldığı tespit edilmiştir. Ders kitapları soy bağı ilişkili metinler açısından değerlendirildiğinde sınıf seviyeleri arasında dengeli bir dağılım olmadığı görülmektedir. Ders kitapları arasında sınıf seviyelerine göre eşit, artan veya azalan bir dağılım yoktur.

Öğrencilerin bulunduğu kademe ve yaş düzeyleri göz önünde bulundurulduğunda soy bağı ilişkilerinin sınıf seviyelerine dengeli veya artan, azalan bir biçimde sunulması daha faydalı olacaktır. Nitekim yetişme çağında bulunan çocukların toplumsal değerleri, kazanımları, kavramları edinmeleri içinde bulundukları yaştan ötürü önem arz etmektedir. Çocukların yaşı ilerledikçe kabul ve uyum düzeyleri zorlaşacağı için zamanında bu kavramları aktarmak önemlidir. Ders kitapları arasındaki bu dengesiz dağılımın sebebi yayınevlerinin farklı olmasından $\mathrm{mı}$, metinlerin doğaçlama seçilmesinden mi yoksa soy bağı ilişkilerine önem verilmediğinden mi kaynaklandığı sonucunu kesin olarak tespit etmek mümkün olamamaktadır.

\section{Üçüncü Alt Amaca ilişkin Bulgular ve Yorum}

Araştırmanın üçüncü alt amacını oluşturan "Soy bağı ilişkileri metin türlerine dengeli dağılmış mıdır?" sorusuna ilişkin bulgular ve yorumlar Tablo 5 'te sunulmuştur. Incelenen metinlerin türlere ayrılmasında metnin özgün türü değil ders kitabında ele alınan şekli esas alınarak analiz yapılmıştır.

Tablo 5.

Soy Bağı Ilişskili Metinlerin Tür Dağılımları

\begin{tabular}{|c|c|c|c|c|c|c|c|c|c|}
\hline \multirow{2}{*}{ Metin Türü } & \multirow{2}{*}{$\begin{array}{c}\text { Metin } \\
\text { Alt Türü }\end{array}$} & \multicolumn{4}{|c|}{ Sınıf Seviyesi } & \multirow{2}{*}{$f$} & \multirow{2}{*}{$\Sigma f$} & \multirow{2}{*}{$\%$} & \multirow{2}{*}{$\Sigma \%$} \\
\hline & & 5. Sinıf & 6. Sinif & 7. Sinıf & 8. Sinıf & & & & \\
\hline & Anı & $\mathrm{M} 1, \mathrm{M} 2$ & M15 & $\mathrm{M} 26, \mathrm{M} 28$ & M37 & 6 & & 14,8 & \\
\hline \multirow[t]{4}{*}{ Bilgilendirici } & Biyografi & - & M20 & M25 & M40 & 3 & 10 & 7,14 & 23,80 \\
\hline & Mektup & - & - & - & M36 & 1 & & 2,38 & \\
\hline & Çizgi Roman & M3 & M18 & M34 & M38 & 4 & & 9,52 & \\
\hline & Fabl & - & M13 & M29 & - & 2 & & 4,76 & \\
\hline \multirow[t]{3}{*}{ Hikâye Edici } & Hikâye & $\begin{array}{l}\text { M4, M6, } \\
\text { M7, M8, } \\
\text { M9, M10 }\end{array}$ & $\begin{array}{c}\text { M11, } \\
\text { M12, } \\
\text { M16, } \\
\text { M21, M22 }\end{array}$ & $\begin{array}{c}M 23, M 27, \\
M 30, M 32 \\
M 33\end{array}$ & $\begin{array}{l}\text { M35, } \\
\text { M39 }\end{array}$ & 18 & 28 & 42,85 & 66,66 \\
\hline & Efsane & - & M17 & - & M41 & 2 & & 4,76 & \\
\hline & Tiyatro & - & - & M31 & M42 & 2 & & 4,76 & \\
\hline Şiir & Şiiir & M5 & M14, M19 & M24 & - & 4 & 4 & 9,52 & 9,52 \\
\hline Toplam & & 10 & 12 & 12 & 8 & 42 & 42 & 100 & 100 \\
\hline
\end{tabular}


Eğitim faaliyetlerinde verimliliği arttırmak, eğitim faaliyetlerini düzenlemek ve eğitimde eşgüdümü sağlamak için eğitim programlarına ihtiyaç vardır (Aslan ve Erden, 2020). Çağın yeniliklerini eğitim sistemlerine yansıtmak adına eğitim programlarında değişiklik yoluna gidilmektedir (Kurudayıŏlu ve Çetin, 2015). Öğrencilere metinler aracılı̆̆ıyla kazanımlar, ahlaki bilgiler, gelenek ve görenekler, dil bilgisi çalışmaları ve dil becerileri kazandırılabilmektedir (Şahin ve Bayramoğlu, 2016). Incelenen Türkçe ders kitaplarında yer alan soy bağı ilişkilerini içeren metinlerin türlere göre analiz edilmesinde Millî Eğitim Bakanlı̆ı̆ın 2019 Türkçe Dersi Öğretim Programı esas alınmıştır. 2019 Türkçe Dersi Öğretim Programı'nda metinler bilgilendirici, hikâye edici ve şiir türleri ile bunların alt türlerine ayrılmaktadır (MEB, 2019). Tablo 5. incelendiğinde toplam 42 metinde üç metin türü ve dokuz alt tür tespit edilmiştir. Bunlar arasından soy bağı ilişkilerini içeren metinlere hikâye edici metinlerde yoğun bir şekilde yer verilirken $(f=28)$ şiir türündeki metinlerde sınırlı düzeyde yer verilmiştir $(f=4)$.

\section{Dördüncü Alt Amaca İlişkin Bulgular ve Yorum}

Araştırmanın dördüncü alt amacını oluşturan "Soy bağı ilişkilerini ele alan metinler görsellerle desteklenmiş midir?" sorusuna ilişkin bulgularla ilgili soy bağı ilişkilerini içeren metinler incelenmiştir. Inceleme kapsamında okuma ve serbest okuma metinleri incelenmiş; 5. sınıf Türkçe ders kitabında yer alan 1, 6. sınıf Türkçe ders kitabında yer alan 2, 7. sınıf Türkçe ders kitabında yer alan 1, 8. sınıf Türkçe ders kitabında yer alan 3 metin olmak üzere toplam 7 dinleme/izleme metni bu kapsama dâhil edilmemiştir.

Görsel bir çağ olan 21. yüzyılda eğitim öğretim ortamlarında ve materyallerinde görsel ögelere ağırlık verilmiştir. Görsel ögeler tüm derslerde kullanılmasına karşın Türkçe dersinde vazgeçilmez bir konuma gelmiştir (Akkaya, 2013). Ders kitaplarında yer alan metinler incelendiğinde dinleme/izleme metinleri dışında kalan metinlerin görseller ile zenginleştirildiği tespit edilmiştir. Dinleme/izleme metinleri ise ilgili yayınevleri tarafından çevrim içi ortamlarda görsel ve işitsel olarak sunulmuştur. Fakat bu metinler ders kitaplarında yer almadıkları ve dinleme/izleme metinlerinin başlıklarının bulunduğu sayfalarda görsellere yer verilmediği için araştırma kapsamına alınmamışlardır. Soy bağı ilişkilerini içeren metinlerin görsellerinde tümünde bu ilişkiler belirgin olarak işlenmemiştir. 5. sınıf Türkçe ders kitabında yer alan M9 ve M10 metinlerinde; 6 . sınıf Türkçe ders kitabında yer alan M12, M13 ve M15 metinlerinde; 7. sınıf Türkçe ders kitabında yer alan M29 ve M33 metinlerinde; 8. sınıf Türkçe ders kitabında yer alan M36 ve M42 metinlerinde soy bağı ile ilişkili görseller yer almamıştır. Soy bağı ilişkilerini içeren metinlerde yer alan görsellerden bazıları olay örgüsünden hareketle aşağıda sunulmuştur:

5. sınıf Türkçe ders kitabındaki "Çocuk Bahçesindeki Bekçi" metninde yer alan görsellerde olayın kahramanı olan ağabey ile kız kardeşinin çocuk parkında oyun oynaması ve kendilerine saldıracak olan çocuklardan korunmak için ağabeyin koruma duygusuyla davranarak kız kardeşini koruması yansıtılmıştır.

6. sınıf Türkçe ders kitabında "Yaz Sinemaları" metninde yer alan görsellerde sinemaya komşularıyla beraber gidecek olan bir ailenin anne, baba, çocuklar ve komşular şeklinde sinemaya gitmesi vurgulanmıştır. Görsellerde aile olmanın, sevginin ve birlikteliğin verdiği samimi ve sıcak ruh hâlleri yansıtılmıştır.

7. sınıf Türkçe ders kitabında "ibni Sina" metninde yer alan görsellerde ilim, irfan öğrenmeyi, kitaplarla iç içe olayı seven bir çocuk olan İbni Sina ve babası arasında geçen diyaloglar yansıtılmıştır. Oğlunun sürekli okumakla meşgul olduğunu gören babanın bir taraftan oğluyla gurur duyması bir taraftan oğlunun çok yorulduğunu düşünmesi yansıtılmıştır.

8. sınıf Türkçe ders kitabında "Kaşă̆ı" metninde yer alan görsellerde baba ve iki oğluna yer verilmiştir. Merakı yüzünden kaşağıyı kıııp suçu kardeşine atan ağabeyin duymuş olduğu pişmanlık ve babanın küçük oğlunun hasta hâli başında iyileşmesini beklemesi yansıtılmıştır. 


\section{Beşinci Alt Amaca ìlişkin Bulgular ve Yorum}

Araştırmanın beşinci alt amacını oluşturan "Soy bağı konusu ile öğrencilere hangi değerler kazandırımak istenmiştir?" sorusuna ilişkin bulgularla ilgili soy bağı ilişkilerini içeren metinler incelenmiş̧ir. Metinlerde yer alan değerlerin tespit edilmesinde 2019 Türkçe Dersi Öğretim Programı (MEB, 2019) ve Swartz'ın (1992) değerler ölçeği sınıflandırması kullanılmıştır.

Tablo 6.

Soy Bağı Illişkili Metinlerde Yer Alan Değerler

\begin{tabular}{|c|c|c|c|c|c|c|}
\hline \multirow{2}{*}{ Değer } & \multicolumn{4}{|c|}{ Sınıf Seviyesi } & \multirow{2}{*}{$f$} & \multirow{2}{*}{$\%$} \\
\hline & 5. Sinıf & 6. Sinif & 7. Sinif & 8. Sinif & & \\
\hline Yardımseverlik & $\begin{array}{l}\text { M2, M6, } \\
\text { M8, M10 }\end{array}$ & $\begin{array}{l}\text { M13, M14, } \\
\text { M16, M20 }\end{array}$ & $\begin{array}{l}\text { M23, M25, } \\
\text { M28, M31, } \\
\text { M32, M33 }\end{array}$ & $\begin{array}{l}\text { M35, M36, } \\
\text { M40 }\end{array}$ & 17 & 17,89 \\
\hline Sevgi & M6, M7 & M17, M19, M22 & $\begin{array}{c}M 23, M 24, \\
M 25, M 29, \\
M 30\end{array}$ & $\begin{array}{l}\text { M36, M37, } \\
\text { M39, M41 }\end{array}$ & 14 & 14,73 \\
\hline Çalışkanlık & $\begin{array}{l}\text { M5, M8, } \\
\text { M10 }\end{array}$ & M22 & $\begin{array}{l}\text { M25, M28, } \\
\text { M34 }\end{array}$ & $\begin{array}{l}\text { M37, M38, } \\
\text { M40 }\end{array}$ & 10 & 10,52 \\
\hline Vatanseverlik & M1 & $\begin{array}{l}\text { M14, M17, } \\
\text { M18, M22 }\end{array}$ & M26 & M36 & 7 & 7,36 \\
\hline Doğa Sevgisi & M4 & M11, M12, M14 & M24, M27 & - & 6 & 6,31 \\
\hline Saygı & M8, M9 & M15, M16, M18 & M32 & - & 6 & 6,31 \\
\hline Fedakarlık & M1, M9 & - & $\mathrm{M} 23, \mathrm{M} 25$ & M36 & 5 & 5,26 \\
\hline Sorumluluk & M1, M10 & M22 & M25 & M40 & 5 & 5,26 \\
\hline Misafirperverlik & M10 & M13, M16 & - & M42 & 4 & 4,21 \\
\hline Sabır & M4 & M18 & M34 & M38 & 4 & 4,21 \\
\hline Dostluk & M6 & - & M23 & M36 & 3 & 3,15 \\
\hline $\begin{array}{l}\text { Kültürel Mirasa } \\
\text { Sahip Çıkma }\end{array}$ & - & - & M26, M28 & M41 & 3 & 3,15 \\
\hline Dürüstlük & - & M18 & - & M35 & 2 & 2,10 \\
\hline Gelenekçilik & - & M11, M15 & - & - & 2 & 2,10 \\
\hline İyilik Yapma & - & - & M23, M30 & - & 2 & 2,10 \\
\hline Paylaşımcı Olma & - & M14 & - & M39 & 2 & 2,10 \\
\hline Empati & - & - & M33 & - & 1 & 1,05 \\
\hline Kanaatkarlık & M2 & - & - & - & 1 & 1,05 \\
\hline Sılayırahim & - & - & - & M39 & 1 & 1,05 \\
\hline Toplam & 21 & 26 & 28 & 20 & 95 & 100 \\
\hline
\end{tabular}

Yardımseverlik; insanların birbirlerine, doğaya, hayvanlara ihtiyacı olanlara faydada bulunma anlamına gelmektedir. Yardımseverlik değeri sanılanın aksine sadece düşkün, muhtaç insanlara hayırda bulunmak anlamına gelmemektedir. Yardımseverlik değerini bu kadar dar bir kalıba sokmak değerin de önemini azaltmak anlamına gelir. İhtiyacı olan bir hayvana yardım eli uzatmak, bir çiçeğe su vermek, yere düşen birini ayağa kaldırmak da yardımseverliktir. Yardımseverlik hayatın her aşamasında insanların karşııına çıkmasına rağmen çoğu zaman suistimal edilmesinden dolayı kalplerin katılaşmasıyla zayıflamaktadır. Yardımseverlik değerinin üzerinde MEB de durmaktadır ve bu sebeple on kök değerden birisi olmuştur. İncelenen metinlerde de en çok işlenen değer olması ( $f=17)$ yardımseverliğin önemini ortaya koymaktadır.

TDK Güncel Türkçe Sözlükte (2021) "insanı bir şeye veya bir kimseye karşı yakın ilgi ve bağlııı göstermeye yönelten duygu" anlamına gelen sevgi çocuklara kazandırılması gereken ilk değerlerin 
başında gelmektedir. Topbaş'a (2019) göre ise sevgi insanların sadece birbirlerine karşı hissettiği bir duygu değil canlı, cansız her şeye karşı hissedilen bir duygudur. Incelenen metinlerde sevgi değeri bir bütün olarak doğa sevgisi, vatanseverlik ve yardımseverlik alt değerleri ele alınarak ile çeşitli şekillerde işlenerek sunulmaktadır.

Çalışkanlık; bir amaca ulaşmak için sabır ve azimle gayret etmek, mücadeleci ruhlu olmak gibi çeşitli anlamlara gelmektedir. Çalışkanlık bireyden bireye, toplumdan topluma değişiklik gösterebilmektedir. Bunun temel sebeplerinden biri çalışkanlığı gözlem, taklit veya model alma yollarıyla öğreniyor olmamızdır. Davranış kalıplarımız, yakınlarımız başta olmak üzere hayatımıza etki eden diğer insanlardan etkilenerek oluşmaktadır (Özdaş, 2020). Eski dönem insanları ile kıyaslanınca günümüzde insanların genel olarak tembelliğe sürüklendiğini söylenebilir. Tembelliğin birçok sebebi vardır. Bunlardan bazılarını: gelişen ve ilerleyen teknoloji, bireylerin hazırcılığa alışmaları, sorumluluk almaktan kaçınma, öz güven ve motivasyon eksikliği, isteksizlik, disiplinsiz ve programsız davranma şeklinde sıralamak mümkündür. Soy bağ ilişkilerini içeren metinlerde geçen bazı değerlerle ilgili doğrudan alıntılar aşağıda sunulmuştur:

Yardımlaşma değeri: "Hasan ağabey, ağabeyimi sırtına almaya çalışıyor, olmuyor. Koltuk altlarından tutuyoruz." (Çapraz-Baran ve Diren, 2019, s. 173).

Sabır değeri: "Artık hiç kuvveti kalmayan Kara Memiş'in eskiden beri gördüğü -kırk yıllık- bir rüyası vardır: Türklerin, Türk gemilerinin gelişi." (Demirel, 2019, s. 223).

Fedakarlık değeri: "Ev işleri ile çok meşgul olmadığı günlerde, beni ön taraftaki yatak odasına götürür ve bana birbiri ardına harfleri öğretmek için saatlerini harcardı." (Erkal ve Erkal, 2019, s. 39).

Sevgi değeri: "Sevgili anacığım, babacığım hasretle ellerinizden öperim. Ben burada çok iyiyim, beni sakın merak etmeyin." (Eselioğlu, Set ve Yücel, 2019, s. 60).

\section{Altıncı Alt Amaca ilişkin Bulgular ve Yorum}

Araştırmanın altıncı alt amacını oluşturan "Soy bağı konusu ile ilgili metinlerde hangi kültürel ögelere yer verilmiştir?" sorusuna ilişkin olarak metinler incelenmiştir. Kültür, bir milleti diğerlerinden farklı kılan yaşam biçimleri ve her milletin kendisine has olan millî değerleridir (Ergin, 1986). Ders kitaplarından hareketle incelenen metinler; örf ve âdetler, tarihi yerler, yiyecek-içecek kültürü, tarihi şahsiyetler, geleneksel oyunlar, çocuk oyunları, dini motifler, zanaatlar gibi çeşitli kültür ögeleri içermeleri bakımından incelenerek sınıf seviyesine göre analiz edilmiştir.

5. sınıf Türkçe ders kitabında soy bağı ilişkilerini içeren metinlerde âşık oynamak, isim verme, miras bırakma, türkü tutturma, Van peyniri, Nasreddin Hoca, komşuluk gibi Türk kültüründe yer edinen çeşitli kültürel ögelere yer verilmiştir. 6. sınıf Türkçe ders kitabında soy bağı ilişkilerini içeren metinlerde türkü söylemek, birdirbir oynamak, ebe oynamak, bitkisel ilaç, şifalı su gibi kültürel ögelere yer verilmiştir. 7. sınıf Türkçe ders kitabında soy bağı ilişkilerini içeren metinlerde Bektaşilik, kervansaray, cami, türbe, saray, köprü, oymacılık, medrese, hamam, Karagöz-Hacivat, komşuluk, kahve içme kültürü gibi Türk kültüründe yer edinen çeşitli kültürel ögelere yer verilmiştir. 8. sınıf Türkçe ders kitabında soy bağı ilişkilerini içeren metinlerde kına yakmak, Karagöz-Hacivat, fal bakma gibi kültürel ögelere yer verilmiştir.

Ders kitaplarında yer alan soy bağı ilişkili metinlerin kültürel ögeler içermeleri bakımından incelenmesinde ders kitabı temelli inceleme yapılmıştır. İncelenen metinlerde her sınıf seviyesinde farklı kültürel ögeler yer almakla birlikte en az kültürel ögelere 12 metin barındırmasına karşın 6 . sınıf Türkçe ders kitabında yer almaktadır. En fazla kültürel öge ise 7. sınıf Türkçe ders kitabında yer almaktadır. Soy bağ ilişkilerini içeren metinlerde geçen bazı kültürel değerlerle ilgili doğrudan alıntılar aşağıda sunulmuştur:

"Meğer sultanım, Dirse Han'ın oğlancığı üç de kabile çocuğu meydanda aşık oynuyorlardı." (Çapraz Baran ve Diren, 2019, s. 119).

"Suyu kazın göl olsun, tüm canlar bu sudan şifalarını bulsun!" (Demirel, 2019, s. 146).

"İ̧̧inde cami, hamam, yatılacak yerler, büyük depolar vardı. Çocuk, kervansarayı büyük hayranlıkla inceliyor, her yere ayrı ayrı bakıyordu." (Erkal ve Erkal, 2019, s. 109).

"Oğlum Ali, yazmışsın ki kafamdaki kınayla dalga geçtiler. Kardeşime de yakma demişsin. Kardeşine de yaktım." (Eselioğlu, Set ve Yücel, 2019, s. 61). 


\section{Sonuç ve Tartışma}

Bilinçli, üretken ve nitelikli bireyler yetiştirmek her toplumda istendik bir amaçtır. Bunu sağlamak ise bireylere sunulacak eğitim faaliyetleri ile mümkündür. Eğitim ise örgün eğitim kurumlarından önce ailede, yakın çevrede başlar. Yakın çevre eğitim sürecinde bireyi şekillendirerek toplumsal değer ve idealleri bireye aktarır. Bu yüzden soy bağı ilişkilerinin önemi yadsınamayacak kadar önemlidir. Türk eğitim sistemi de millî ve kültürel değerlerin korunması ve bunların sonraki kuşaklara aktarılması esasını gözetmektedir. Bunu sağlarken doğrudan bir iletişim aracı olarak ders kitaplarından faydalanılmaktadır. Yapılan bu araştırmada da Millî Eğitim Bakanlığının ortaokul düzeyinde okuttuğu Türkçe ders kitapları soy bağı ilişkileri açısından incelenerek bulgular belirlenen alt amaçlara göre değerlendirilmiştir.

Araştırmanın birinci alt amacına ilişkin Türkçe ders kitaplarında yer alan soy bağı ilişkili 42 metin incelenmiş ve bu metinlerde geçen soy bağı kavramları tasnif edilmiştir. İnceleme sonucunda soy bağına özgü 18 farklı kavramın toplam 548 defa geçtiği tespit edilmiştir. Bu kavramlar metinlere dengeli dağılmamış ve bazı kavramlara metinlerde yer verilmemiştir. Metinlerde en çok baba kavramı kullanılırken, yenge, teyze gibi kavramlar çok az geçmektedir. Hala, yeğen gibi soy bağını ifade eden bazı kavramlar ise metinlerde hiç yer almamaktadır. Bu açıdan kavramların seçiminde dengeli bir dağılım tespit edilmemiştir. Metinlerde yer alan kavramlar bir bütün olarak incelendiğinde 18 farklı kavramın olması ve bu kavramların 548 defa tekrarlanması soy bağııı göz ardı edilmediğini sadece dengeli bir dağılım olmadığını göstermektedir. Giriş kısmındaki kaynaklardan da faydalanarak soy bağının önemi burada açıklanabilir, soy bağı kavramlarının dengeli bir şekilde metinlerde yer alması gerektiği yorumlanabilir. Demirgüneş, Çelik ve iş̧eri (2015) yaptıkları araştırmada akrabalık kavramlarının dağılımları arasında düzensiz bir dağılım olduğunu tespit etmişlerdir.

Araştırmanın ikinci alt amacını oluşturan bulgulardan hareketle Türkçe ders kitaplarında yer alan soy bağı ilişkili metinler incelendiğinde 4 sınıf düzeyinde yer alan 160 okuma ve dinleme/izleme metninden 42 tanesinin soy bağı ile ilişkili olduğu tespit edilmiştir. Sınıf düzeyleri açısından dengesiz bir dağılım olmasına karşın her sınıf düzeyinde soy bağına önem verildiği görülmektedir. Ortaokul düzeyinde yer alan metinlere nicel açıdan bakıldığında 160 metinden 42 tanesinin soy bağı ilişkili konular içermesi her dört metinden birinin soy bağı ekseninde seçildiğini ve bu noktada soy bağına önem verildiği görülmektedir.

Araştırmanın üçüncü alt amacını oluşturan bulgulardan hareketle Türkçe ders kitaplarında yer alan soy bağı ilişkili metinler 2019 Türkçe Öğretim Programı'nda yer alan bilgilendirici, hikâye edici, şiir metin türleri ve bu metin türlerinin alt türlerinden hareketle incelenmiştir. Metinlerde bilgilendirici, hikâye edici, şiir türleri ve bu türlerin alt türleri olan dokuz metin türü tespit edilmiştir. Metin alt türlerinin dağılımları incelendiğinde hikâye türüne çok yer verilirken gezi yazısı, destan, şarkı/türkü gibi türlere hiç yer verilmemiştir. Soy bağı ilişkili metinlerde metin türleri arasındaki dengesiz dağılım diğer metin türlerinin değerinin düşmesine sebebiyet vermektedir. Yılmaz ve Korkmaz (2016) da 1-5. sınıf Türkçe kitapları ile ilgili yaptıkları benzer bir araştırmada metin türlerinin ders kitaplarına dengeli dağılmadığını tespit etmişlerdir.

Araştırmanın dördüncü alt amacını oluşturan bulgulardan hareketle Türkçe ders kitaplarında yer alan soy bağı ilişkili metinler görsellerle desteklenme açısından incelenerek görselleri metin ve konuyla uyumlarına dikkat edilmiştir. İncelenen 42 metinden yedi tanesi dinleme/izlemeye dayalı olup metinde parça olmamasından dolayı kapsam dışında bırakılmışır. Metinlerde yer alan görseller bir bütün olarak incelendiğinde soy bağı ilişkilerini içeren 35 okuma metninden 26 tanesi soy bağı ile ilişkili olduğu tespit edilmiştir. Buradan kasıt görsellerin doğrudan soy bağı içerikli olmasıdır. 35 metnin dışında geri kalan yedi metinde de görsel kullanılmış fakat bu metinler, soy bağı ilişkilerini temsil edici değildirler. Görseller, çocukların hayal güçlerini ve yaratıcılıklarını tetikleyerek algı dünyalarını hitap ettikleri için önem arz ederler. Çocuklar kendilerini ifade etme ve kendilerinden bir parçayı metinlerde bulup derse, kitaba, metne ve çevresine karşı bir benimseme hisseder. Soy bağı ilişkili metinlerde görsellere yer verilmesi bu sebeple önemlidir. Metinler bir bütün olarak incelendiğinde 35 okuma metninden 26 'sının görsellerle zenginleştirilmesi öğrencilerin metinleri içselleştirmesine daha fazla imkân tanımaktadır. İşcan ve Cımbız (2018) yaptıkları araştırmada görsellerin 5. sınıf Türkçe ders kitaplarının metinlerle uyumları incelenmiş ve görsellerin öğrencilerin 
metinleri tahmin etmesine imkân tanıdığı tespit edilmiştir. Yılmaz (2005), Bulut Tutkun (2008) ve Batur (2010) yapmış oldukları araştırmalarda görsellerin, metinlerin içeriğiyle kısmen uyumlu olduğunu belirtmişlerdir.

Araştırmanın beşinci alt amacını oluşturan bulgulardan hareketle Türkçe ders kitaplarında yer alan soy bağı ilişkili metinler değerler eğitimi açısından incelenmiş ve 19 farklı değer tespit edilmiştir. Metinlerde birbirinden farklı 19 değerin yayılım göstermesi ve bu değerlerin ders kitaplarına birbirine yakın bir dağılım göstermesi metinlere zenginlik katmaktadır. Bu açıdan metinlerin değer bakımından zengin olduğu tespit edilmiştir. Fakat MEB'in 2019 öğretim programlarında belirlemiş olduğu 10 kök değerden adalet ve öz denetim değerlerine metinlerde yer verilmediği tespit edilmiştir. Şakiroğlu (2020) 6. sınıf Türkçe ders kitapları ile ilgili yaptığı araştırmada adalet ve dürüstlük değerine çok az yer verildiğini ifade etmektedir. Topbaş (2019) 6. sınıf Türkçe ders kitapları ile ilgili yaptığı araştırmada ders kitabında yer alan değer dağılımlarında bir denge olmadığını, değer aktarımını bir plan dâhilinde, sistematik olarak hazırlanmadığını belirtmektedir. Özdaş, Çakmak ve Öter'in (2017) yaptığı araştırmada ortaokul öğretim programlarında yer alan değerlerin; bireyler arası ilişkiler, millî değerler, evrensel değerler ve özerklik boyutlarında kısmen düzeyinde aktarıldı̆̆ı tespit edilmiştir.

Yetişme çağında olan ortaokul kademesi öğrencilerinin kültürlerini tanımaları yaşadıkları coğrafyaya hâkim olmaları bakımından önemlidir. Ders kitaplarında yer alan metinlerde yer verilen kültürel ögeler öğrencilerin metinlere olan ilgisini arttırarak okuma sürecini daha eğlenceli ve verimli hâle getirmektedir. Araştırmada incelenen metinlerde farklı sınıf seviyelerinde ve farklı metinlerde Türkiye'nin iklimini tanıtıcı kültürel ögelere yer verilmiştir. Bu durum öğrencilere içinde yaşadıkları toplumu tanımaları için imkân vermektedir. Fakat ders kitaplarının incelenmesinde zengin bir kültür altyapısına sahip olan toplumda kültürel çeşitliliğe ders kitaplarında az yer verilmiştir. Şahin (2015) 4. sınıf ders kitaplarıyla ilgili yaptığı araştırmada Türkçe ders kitaplarında kültürel ögelerin yetersiz olduğunu ve toplumda sıklıkla karşılaşılan ögelerin ders kitaplarında yer almadığını tespit etmiştir. Kırkkeseli (2017) 8. sınıf Türkçe ders kitapları ile ilgili yaptığı araştırmada millî dokulara, millî ürünlere ve sanatsal değerlere çok az yer verildiğini tespit etmiştir. Kan (2010) 7. sınıf Türkçe ders kitapları ile ilgili yaptığı araştırmada millî giyim, kuşam ögelerinin yetersiz kaldığını belirtmektedir.

Yapılan araştırmanın sonuçlarından hareketle aşağıdaki önerilerde bulunulmuştur.

- Diğer ders kitaplarında da soy bağı konusunun incelenerek daha geniş bir tartışma alanı oluşturulmasında fayda vardır.

- Öğretim programlarında yer alan kök değerlerin ders kitaplarında yer alan metinlerde yer alması faydalı olacaktır.

- Ders kitaplarında kültürel çeşitliliğe daha fazla yer verilmesinde fayda vardır.

- Bu araştırma doküman taraması modeliyle yürütülmüştür. Soy bağı ile ilgili öğretmen ve/veya öğrenci görüşlerinin ele alınacağı bir araştırmanın yapılması alanyazına katkı sağlayacaktır.

- Bu araştırmada ortaokul (5, 6, 7 ve 8. sınıf) Türkçe ders kitapları incelenmiştir. Benzer bir araştırma ilkokul (1, 2, 3 ve 4. sınıf) Türkçe ders kitapları ile yürütülebilir.

\section{Araştırma ve Yayın Etiği}

Bu araştırmada "Yükseköğretim Kurumları Bilimsel Araştırma ve Yayın Etiği Yönergesi" kapsamında uyulması belirtilen tüm kurallara uyulmuştur. Yönergenin ikinci bölümü olan "Bilimsel Araştırma ve Yayın Etiğine Aykırı Eylemler" başlığı altında belirtilen eylemlerden hiçbiri gerçekleştirilmemiştir.

\section{Yazarların Katkı Oranı}

Birinci yazar araştırma konusunun ortaya konulması, literatür taramasının yapılması, verilerin toplanması ve incelenmesinde (\%50); ikinci yazar araştırma konusunun geliştirilmesi, araştırma verilerinin ve yöntem kısmının incelenmesinde (\%40); üçüncü yazar araştırma verilerinin toplanmasında (\%10) katkıda bulunmuştur.

\section{Çıkar Çatışması}

Araştırmada çıkar çatışması teşkil edecek herhangi bir durum ya da ilişki yoktur. 


\section{Kaynaklar}

Adıgüzel, A. (2010). Illköğretim okullarında öğretim teknolojilerinin durumu ve sınıf öğretmenlerinin bu teknolojileri kullanma düzeyleri. Dicle Üniversitesi Ziya Gökalp Eğitim Fakültesi Dergisi, (15), 1-17.

Akkaya, A. (2013). Türkçe derslerinde ders kitabı dışında görsel öge kullanmaya ilişkin Türkçe öğretmenlerinin görüşlerinin incelenmesi. Journal of Turkish Studies, 8(9), 471-479. DOI: 10.7827/TurkishStudies.5562

Akpınar, B. (2013). Eğitimde program geliştirme. Ankara: Data Yayınları

Aslan, M. ve Erden, R. (2020). Ortaokul öğretmenlerinin öğretim programına bağlılıklarııın incelenmesi. Yüzüncü Yıl Üniversitesi Eğitim Fakültesi Dergisi, 17(1), 175-199. DOI: 10.33711/yyuefd.691525

Batur, Z. (2010). Anadili öğretiminde gösterge bilimin yeri: Ana dili ders kitaplarındaki sözel metinlerle gösterge metinleri bütünselliğinin analizi. Turkish Studies, 5(4), 174-200. DOI: 10.7827/TurkishStudies.1713

Belet Boyacı, Ş. ve Güner Özer, M. (2019). Öğrenmenin geleceği: 21. yüzyıl becerileri perspektifiyle Türkçe dersi öğretim programları. Anadolu Journal of Educational Sciences International, 9(2), 708-738. DOI: 10.18039/ajesi.578170

Bulut Tutkun, S. (2008). Ilköğretim ders kitaplarının görsel boyutu ve içerik tutarlılı̆ı açısından incelenmesi (Yayımlanmamış yüksek lisans tezi). Niğde Ömer Halisdemir Üniversitesi Sosyal Bilimler Enstitüsü, Niğde.

Çapraz Baran, Ş. ve Diren, E. (2020). Türkçe 5. sınıf ders kitabı. Ankara: Anıttepe Yayıncılık.

Çelikpazu, E. E. ve Aktaş, E. (2011). MEB 6, 7 ve 8. sınıf Türkçe ders kitaplarında yer alan metinlerin değer iletimi açısından incelenmesi. Turkish Studies, 6(2), 413-424. DOI: 10.7827/TurkishStudies.2274

Demir, D. ve Akkaya, A. (2020). Ortaokul 8. sınıf öğrencilerinin konuşma kavramına ilişkin algılarının çizdikleri görseller aracılığıyla incelenmesi. International Journal of Languages Education, 8(4), 1-18. DOI: 10.29228/ijlet.48231

Demirel, T. (2020). Türkçe 6. sınıf ders kitabı. Ankara: Ekoyay Yayıncılık.

Demirgüneş, S., Çelik, T. ve İşeri, K. (2015). Türkçe ders kitaplarında akrabalık kavramları. Researcher: Social Science Studies, 3(2), 1-13. DOI: 10.18301/rsss.38

Emiroğlu, S. (2012). Türkçe sözlükteki akrabalık adlarının tasnifi. Turkish Studies, 7(4), 1691-1710. DOI: 10.7827/TurkishStudies.3872

Ergin, M. (1986). Üniversiteler için Türk dili. İstanbul: Boğaziçi Yayınları.

Erkal, H. ve Erkal, M. (2020). Türkçe 7. sınıf ders kitabı. Ankara: Özgün Matbaacılık.

Ertuğrul, B. ve Ertuğrul, O. (2016). Lûgat 365-Bazı kelimeler çok güzel. İstanbul: Can Yayınları.

Eselioğlu, H., Set, S. ve Yücel, A. (2020). Türkçe 8. sınıf ders kitabı. Ankara: Tuna Matbaacılık.

Evran Acar, F. (2005). Eğitim fakültelerinin sınıf öğretmenliği programından mezun olan öğretmenlerin Türkçe, sosyal bilgiler, matematik ve fen bilgisi alan ve alan öğretimi yeterliklerinin belirlenmesi ve değerlendirilmesi (Yayımlanmamış doktora tezi). Gazi Üniversitesi Eğitim Bilimleri Enstitüsü, Ankara.

Haviland, W., Prins, H. E. L., Walrath, D. ve Mcbride, B. (2008). Kültürel antropoloji (i. D. Erguvan Sarıoğlu, Çev.). İstanbul: Kaknüs Yayınları.

İnanç, B. Y. ve Bilgin, M. (2004). Gelişim psikolojisi çocuk ve ergen gelişimi. Adana: Nobel Kitabevi.

İşan, A. ve Cımbız, A. (2018). Ortaokul 5. sınıf Türkçe ders kitabındaki resimlerin metinlerle uyum düzeyinin incelenmesi. Abant İzzet Baysal Üniversitesi Eğitim Fakültesi Dergisi, 18(1), 250272. DOI: 10.17240/aibuefd.2018..-380009

Kan, M. O. (2010). Millî eğitim bakanlığı yayınları ilköğretim 7. sınıf Türkçe ders kitabının kültür ögeleri açısından incelenmesi (Yayımlanmamış yüksek lisans tezi). Mustafa Kemal Üniversitesi Sosyal Bilimler Enstitüsü, Hatay.

Karadağ, R., Kolaç, E. ve Ulaş, A. H. (2012). Türkçe öğretmeni adaylarının "Kültür" kavramına yükledikleri anlamlar ve popüler kültüre bakışları. Illköğretim Online, 11(2), 381-394. 
Karakaş, R. ve Akın, E. (2018). Değerler eğitimi bağlamında Siirt menkıbeleri. Folklor/Edebiyat, 24(94), 87-101. DOI: 10.22559/folklor.226

Karasar, N. (2006). Bilimsel araştırma yöntemi. Ankara: Nobel Yayın Dağıtım.

Kırkkeseli, Ö. (2017). 8. sınıf Türkçe ders kitabında yer alan şiir ve okuma metinlerinin kültürel ögeler açısından değerlendirilmesi (Yayımlanmamış yüksek lisans tezi). Atatürk Üniversitesi Eğitim Bilimleri Enstitüsü, Erzurum.

Kurudayığlu, M. ve Çetin, Ö. (2015). Temel beceriler ve Türkçe öğretimi. Ana Dili Eğitimi Dergisi, 3(3), 1-19. DOI: 10.16916/aded.65619

Marshall, G. (1999). Sosyoloji sözlügü (O. Akınhay ve D. Kömürcü, Çev.). İstanbul: Bilim ve Sanat Yayınları.

MEB. (1973). Milli eğitim temel kanunu. Ankara: Millî Eğitim Bakanlığı.

MEB. (2019). Türkçe dersi öğretim programı. Ankara: Millî Eğitim Bakanlığı.

Merriam, S. (1998). Qualitative research and case study applications in education. San Francisco: Jossey-Bass.

Özbay, F. (2014). Akrabalık ve komşuluk ilişkileri. Ankara: T.C. Aile ve Sosyal Politikalar Bakanlığı.

Özdaş, F. (2020). Çalışkanlık. C. Yaşaroğlu ve H. F. Ergül (Ed.), Etik ve insani değerler içinde (53-76). Ankara: Nobel Akademik Yayıncllık.

Özdaş, F. ve Çakmak, M. (2018). Öğretmen adaylarının öğretmenlik uygulaması dersine ilişkin metaforik algıları. Uluslararası Türkçe Edebiyat Kültür Eğitim Dergisi, 7(4), 2747-2766.

Özdaş, F., Çakmak, M. ve Öter, Ö. M. (2017). Öğretmen görüşlerine göre ortaokul öğretim programlarındaki değerlerin kazandırılma düzeyinin incelenmesi. The Journal of Academic Social Science, 5(63), 193-206. DOI: 10.16992/ASOS.13284

Schwartz, S. (1992). Universals in the content and structure of values: Theoretical advances and empirical tests in 20 countries. M. P. Zanna (Ed.), Advances in Experimental Social Psychology (1-65). San Diego: Academic Press.

Şahin, D. ve Bayramoğlu, C. D. (2016). 2015 Türkçe öğretim programının metin tür ve tema seçimi bakımından değerlendirilmesi. Turkish Studies, 11(3), 2095-2130. DOI: 10.7827/TurkishStudies.9289

Şahin, N. (2015). Illkokul 4. sınıf Türkçe ders kitabı metinlerinin kültürel değerler açısından incelenmesi (Yayımlanmamış yüksek lisans tezi). Necmettin Erbakan Üniversitesi Eğitim Bilimleri Enstitüsü, Konya.

Şakiroğlu, Y. (2020). 6. sınıf Türkçe ders kitabının değer aktarımı bağlamında incelenmesi. Türkiye Eğitim Dergisi, 5(1), 145-161.

TDK. (2021). Güncel Türkçe sözlük. Erişim adresi: https://sozluk.gov.tr

Topbaş, G. (2019). 6. sınıf Türkçe ders kitabının değerler açısından incelenmesi (Yayımlanmamış yüksek lisans tezi). Afyon Kocatepe Üniversitesi Sosyal Bilimler Enstitüsü, Afyonkarahisar.

Turhan, M. (2002). Kültür değişmeleri. İstanbul: Çamlıca Yayınları.

Tuztaş, T. (2004). Kültür ve ideal kültür. Sakarya Üniversitesi Eğitim Fakültesi Dergisi, 4(8), 10-27.

Türkben, T. (2019). Türkçe ders kitaplarındaki metinlerin ilettiği değerler açısından incelenmesi. Ana Dili Eğitim Dergisi, 7(3), 508-226. DOI: 10.16916/aded.541659

Yıldırım, A. ve Şimşek, H. (2018). Sosyal bilimlerde nitel araştırma yöntemleri. Ankara: Seçkin Yayıncilık.

Yılmaz, A. (2005). ilköğretim okulları ilk kademede okutulan ders kitaplarının resimlemeleri yönünden değerlendirilmesi (Yayımlanmamış yüksek lisans tezi). Anadolu Üniversitesi Eğitim Bilimleri Enstitüsü, Eskişehir.

Yılmaz, M. ve Korkmaz, C. (2016). İlköğretim 1-5. sınıf Türkçe ders kitaplarındaki metinlerin tür ve tema açısından incelenmesi. Mustafa Kemal Üniversitesi Sosyal Bilimler Enstitüsü Dergisi, 13(36), 33-46. 


\section{Introduction}

\section{Extended Abstract}

This study aims to examine and evaluate the texts in Turkish textbooks in terms of their handling of family and relatives relationships. In this context, the 5th, 6th, 7th, and 8th-grade Turkish textbooks that the Ministry of National Education teaches at the secondary school level in the 20202021 academic year have been examined in terms of lineage relations. With the study, it was aimed to determine the functions of transferring kinship relations of Turkish textbooks to children.

The study aims to teach the students the genealogical relations in the texts of Turkish textbooks and to make them adopt; determining the effect on education is important in terms of determining the value given to family and relative relations in textbooks and revealing the deficiencies in this field.

Based on the purpose of the study, the following research questions were addressed:

1. Which concepts of lineage are included in the texts that include lineage relationships?

2. Are the texts containing lineage relationships evenly distributed across class levels?

3. Are lineage relationships evenly distributed across text types?

4. Are the texts dealing with lineage relationships supported by visuals?

5. Which values are intended to gain students with the subject of lineage?

6. Which cultural elements are included in the texts on the subject of lineage?

\section{Method}

The qualitative research method was used in this study. Document analysis technique, one of the data collection techniques, was used to collect data within the scope of the research. Within the scope of the study, Turkish textbooks used in secondary schools in the 2020-2021 academic year by the Ministry of National Education were used as study materials.

In the research conducted, in the 5th, 6th, 7th, and 8th-grade Turkish textbooks that the Ministry of National Education teaches in secondary schools; a total of 160 texts, 96 of which were 24 reading texts in each textbook, 32 as 8 listening/watching texts in each textbook and 8 free reading texts in each textbook, were scanned in terms of lineage relations and the data was collected. The data collected through the document review method were analyzed with content analysis. 42 texts containing lineage relationships were identified in the textbooks that were analyzed. To facilitate the analysis and reading of the data, the texts containing the lineage relationships are written as "M1, $M 2, M 3$, etc." coded with abbreviations such that.

\section{Result and Discussion}

Regarding the first sub-aim of the study, 42 texts related to lineage in Turkish textbooks were examined and the concepts of lineage mentioned in these texts were classified. As a result of the examination, it was determined that 18 different concepts specific to lineage were mentioned 548 times in total. These concepts are not evenly distributed in the texts and some concepts are not included in the texts. While the concept of the father is mostly used in the texts, concepts such as aunt and aunt are rarely mentioned. Still, some concepts that express descent, such as nephew, are not included in the texts at all. In this respect, a balanced distribution has not been determined in the selection of concepts.

Based on the findings that constitute the second sub-purpose of the study, when the texts related to lineage in Turkish textbooks were examined, it was determined that 42 of 160 reading and listening/watching texts at 4-grade levels were related to lineage. Although there is an unbalanced distribution in terms of class levels, it is seen that lineage is emphasized at every grade level.

Based on the findings that constitute the third sub-purpose of the study, the texts related to lineage in Turkish textbooks were examined concerning the informative, narrative, poetry text types and sub-types of these text types in the 2019 Turkish Education Program. In the texts, nine text types, which are informative, narrative, poetry types, and sub-types of these genres, have been determined. When the distribution of text sub-types is examined, while the story genre is mostly included, there are no genres such as travel writing, epic, song/folk song. 
Based on the findings that constitute the fourth sub-purpose of the study, the texts related to lineage in Turkish textbooks were examined in terms of supporting them with visuals, and attention was paid to the harmony of the images with the text and the subject. Seven of the 42 texts analyzed were based on listening/watching and were excluded due to the absence of parts in the text. When the visuals in the texts are examined as a whole, it has been determined that 26 of the 35 reading texts that contain descent relations are related to lineage. What we mean by this is that the images are of direct descent content. Apart from the 35 texts, the remaining seven texts use images, but these texts are not representative of lineage relationships.

Based on the findings that constitute the sixth sub-purpose of the study, the texts related to lineage in Turkish textbooks were examined in terms of values education and 19 different values were determined. The distribution of 19 different values in the texts and the close distribution of these values in the textbooks adds richness to the texts. In this respect, it has been determined that the texts are rich in value. However, it has been determined that the 10 root values determined by the Ministry of National Education in the 2019 curriculum are not included in the texts of justice and self-control values.

The cultural elements included in the textbooks increase the students' interest in the texts and make the reading process more enjoyable and productive. In the texts examined in the study, cultural elements that introduce the climate of Turkey at different class levels and in different texts were included. This situation gives students the opportunity to get to know the society they live in. However, in a society that has a rich cultural background in the analysis of textbooks, cultural diversity has been given little place in the textbooks. 